\title{
Ion channels gated by acetylcholine and serotonin: structures, biology, and drug discovery
}

\author{
Zhong-shan $\mathrm{WU}^{1,2}$, Hao $\mathrm{CHENG}^{2}$, Yi JIANG ${ }^{2}$, Karsten MELCHER ${ }^{3}, \mathrm{H}$ Eric XU ${ }^{2,3, *}$ \\ ${ }^{1}$ Britton Chance Center for Biomedical Photonics, Wuhan National Laboratory for Optoelectronics, Huazhong University of Science \\ and Technology, Wuhan 430074, China; ${ }^{2}$ VARI-SIMM Center, Center for Structure and Function of Drug Targets, CAS-Key Laboratory \\ of Receptor Research, Shanghai Institute of Materia Medica, Chinese Academy of Sciences, Shanghai 201203, China; ${ }^{2}$ Laboratory of \\ Structural Sciences, Van Andel Research Institute, Grand Rapids, MI 49503, USA
}

\begin{abstract}
The nicotinic acetylcholine receptors (nAChRs) and the $5-\mathrm{HT}_{3}$ receptors $\left(5-\mathrm{HT}_{3} \mathrm{Rs}\right)$ are cation-selective members of the pentameric ligand-gated ion channels ( $p L G I C s$ ), which are oligomeric protein assemblies that convert a chemical signal into an ion flux through postsynaptic membrane. They are critical components for synaptic transmission in the nervous system, and their dysfunction contributes to many neurological disorders. The diverse subunit compositions of pLGICs give rise to complex mechanisms of ligand recognition, channel gating, and ion-selective permeability, which have been demonstrated in numerous electrophysiological and molecular biological studies, and unraveled by progress in studying the structural biology of this protein family. In this review, we discuss recent insights into the structural and functional basis of two cation-selective pLGICs, the $n A C h R$ and the $5-H_{3} R$, including their subunit compositions, ligand binding, and channel gating mechanisms. We also discuss their relevant pharmacology and drug discovery for treating various neurological disorders. Finally, we review a model of two alternative ion conducting pathways based on the latest 5- $\mathrm{HT}_{3 \mathrm{~A}}$ crystal structure.
\end{abstract}

Keywords: nAChR; 5- $\mathrm{HT}_{3} \mathrm{R}$; structure biology; subunit composition; channel activation; channel gating; ion selectivity; neurological disorders

Acta Pharmacologica Sinica (2015) 36: 895-907; doi: 10.1038/aps.2015.66

\section{Introduction}

The nicotinic acetylcholine receptors ( $\mathrm{AAChRs}$ ) and the 5 -hydroxytryptamine type 3 receptors $\left(5-\mathrm{HT}_{3} \mathrm{Rs}\right)$ are cationselective members of the pentameric ligand-gated ion channels (pLGICs), which also include the anion-selective GABA and glycine receptors, the cation channel homologs in prokaryotes (including the bacterial Erwinia chrysanthemi ligand-gated ion channel (ELIC) and the Gloebacter violaceus ligand-gated ion channel (GLIC)) and the anion-selective homolog in invertebrates (the glutamate-gated chloride channel (GluCl)) (Figure 1).

Both $\mathrm{nAChRs}$ and $5-\mathrm{HT}_{3}$ Rs comprise five subunits arranged around a central ion-conducting pore that is permeable to cations including $\mathrm{Na}^{+}, \mathrm{K}^{+}$and $\mathrm{Ca}^{2+}$ when the receptors are activated $^{[1-3]}$. These receptors exist in different inter-convertible conformational states that are triggered by the binding of ago-

\footnotetext{
* To whom correspondence should be addressed.

E-mail eric.xu@vai.org

Received 2015-05-20 Accepted 2015-06-24
}

nists, antagonists, or allosteric modulators ${ }^{[4]}$ (Figure 2).

The nAChRs and $5-\mathrm{HT}_{3}$ receptors are expressed throughout the central nervous system $(\mathrm{CNS})^{[5,6]}$ and peripheral nervous system (PNS) ${ }^{[7]}$ and mediate a variety of physiological functions. The nAChRs are potential therapeutic targets for multiple central nervous system disorders such as schizophrenia, Alzheimer's disease, Parkinson's disease and nicotine addiction $^{[8-11]}$. Moreover, ligands that target the $5-\mathrm{HT}_{3} \mathrm{Rs}$ are powerful therapeutic agents for the control and treatment of drug and alcohol dependence, schizophrenia, anxiety, and cognitive dysfunction, as well as chemotherapy-induced and post-operative nausea and vomiting ${ }^{[12-15]}$. As such, both nAChRs and $5-\mathrm{HT}_{3} \mathrm{Rs}$ have been the targets of drug discovery efforts for many years. Some of these efforts have gone beyond clinical evaluation and led to marketed drugs ${ }^{[16]}$. A more comprehensive understanding of the connection between the structure and function of these receptors could facilitate ongoing drug discovery efforts. In this review, we summarize the current structural and functional knowledge of the nAChRs and the 5- $\mathrm{HT}_{3}$ Rs. 


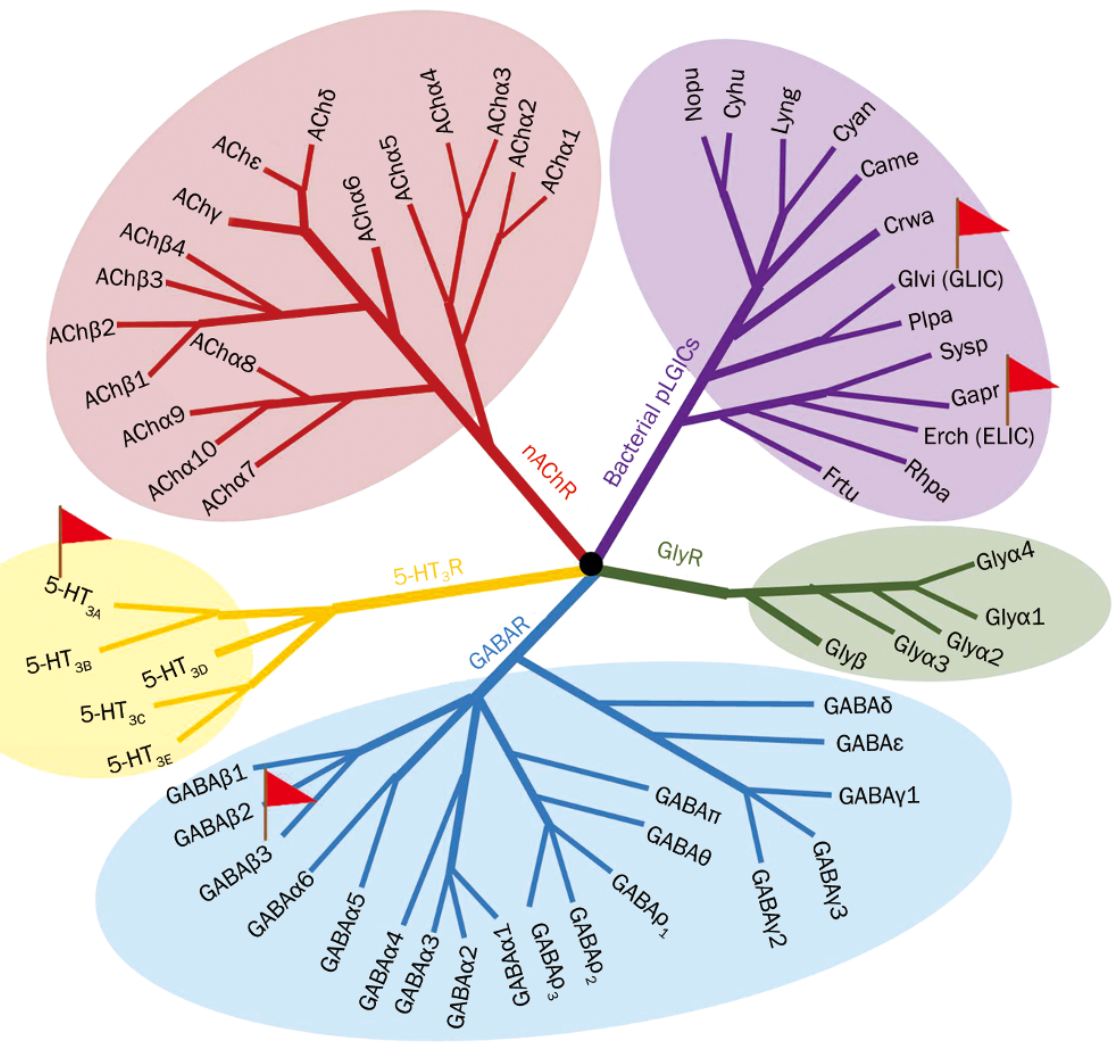

Figure 1. Phylogenetic tree showing the relationship between the pentameric ligand-gated ion channels (pLGICs). Red: the nicotinic acetylcholine receptors (nAChRs); yellow: the 5- $\mathrm{HT}_{3} \mathrm{Rs}$; blue: gamma-aminobutyric acid receptors (GABARs); army green: glycine receptors (GlyRs); and purple: bacterial pLGICs. The red flags indicate the members whose X-ray structure has been determined.

\section{Receptor subunits and components}

To date, seventeen $\mathrm{nAChR}$ subunits and five $5-\mathrm{HT}_{3} \mathrm{R}$ subunits have been identified. The $\mathrm{nAChR}$ subunits include multiple $\alpha(\alpha 1-\alpha 10)$ and $\beta$ subunits $(\beta 1-\beta 4)$ as well as $\delta, \gamma$, and $\varepsilon$ subunits, and the $5-\mathrm{HT}_{3} \mathrm{R}$ subunits include $\mathrm{A}, \mathrm{B}, \mathrm{C}, \mathrm{D}$, and $\mathrm{E}$ subtypes ${ }^{[17]}$. These subunits have been highly conserved through evolution and each single subunit has more than $80 \%$ amino acid identity across vertebrate species. The $\mathrm{nAChR}$ subunits can be divided into four subfamilies (I-IV) based on similarities in protein sequence, and the classification of $5-\mathrm{HT}_{3} \mathrm{R}$ subunits is relatively simple ${ }^{[18]}$ (Figure 3).

The diversity in subunit composition may influence the characteristics of nAChRs and 5- $\mathrm{HT}_{3} \mathrm{Rs}$, including their agonist sensitivity, channel kinetics, $\mathrm{Ca}^{2+}$ permeability, assembly, interactions with chaperones, trafficking and cell localiza$\operatorname{tion}^{[19-23]}$. Muscle-type nAChRs are composed of $\alpha 1, \beta 1, \gamma$, and $\delta$ subunits in a 2:1:1:1 ratio or composed of $\alpha 1, \beta 1, \delta$ and $\varepsilon$ subunits in a 2:1:1:1 ratio. Neuronal-type receptors are homomeric or heteromeric combinations of twelve different nicotinic receptor subunits, $\alpha 2-\alpha 10$ and $\beta 2-\beta 4$, such as $(\alpha 4)_{3}(\beta 2)_{2}$, $(\alpha 4)_{2}(\beta 2)_{3}$, or $(\alpha 7)_{5}{ }^{[24]}$. A functional $5-\mathrm{HT}_{3}$ receptor may be composed of five identical $5-\mathrm{HT}_{3 \mathrm{~A}}$ subunits (homopentameric) or a mixture of $5-\mathrm{HT}_{3 \mathrm{~A}}$ and one of the other four $5-\mathrm{HT}_{3 \mathrm{~B}}, 5-\mathrm{HT}_{3 \mathrm{C}}$ $5-\mathrm{HT}_{3 \mathrm{D}}$, and $5-\mathrm{HT}_{3 \mathrm{E}}$ subunits (heteropentameric) ${ }^{[25]}$.

The homomeric $\mathrm{nAChR}$ and $5-\mathrm{HT}_{3} \mathrm{Rs}$ have five identical ligand binding sites located at the interface between two adja- cent subunits ${ }^{[26]}$. Each heteromeric nAChR contains two agonist binding sites with different affinities. Although the subunit stoichiometry of the heteromeric $5-\mathrm{HT}_{3} \mathrm{Rs}$ is not clearly studied, it was demonstrated that agonists bind to an interface between two adjacent $5-\mathrm{HT}_{3 \mathrm{~A}}$ subunits in the heteromeric $5-\mathrm{HT}_{3 \mathrm{AB}}$ receptor ${ }^{[27]}$, which may explain why the $5-\mathrm{HT}_{3 \mathrm{~A}}$ subunit is essential to form functional $5-\mathrm{HT}_{3}$ receptors. Because the binding sites cooperate, all sites need to be occupied with agonist to fully activate the ion channel. Elucidation of the influence of subunit composition on ligand binding and channel function will be an important topic of future research on these two receptors.

\section{Definition and physiological functions}

In the human nervous system, nicotinic cholinergic signals are extended throughout the system, where the neurotransmitter acetylcholine $(\mathrm{ACh})$ plays a key role in activating ligand-gated ion channels, which is one of the most important and oldest modulatory neurotransmitter systems ${ }^{[28]}$. ACh is synthesized in specific neurons by choline acetyltransferase from choline and acetyl-CoA. The enzyme acetylcholinesterase converts ACh into inactive metabolites choline and acetic acid in the intercellular space. The degradation products can be transported back into the nerve cells by specific transporters ${ }^{[29]}$. Importantly, $\mathrm{ACh}$ is released from presynaptic neurons and binds to the nAChRs that modulate the flow of ions across the 
A

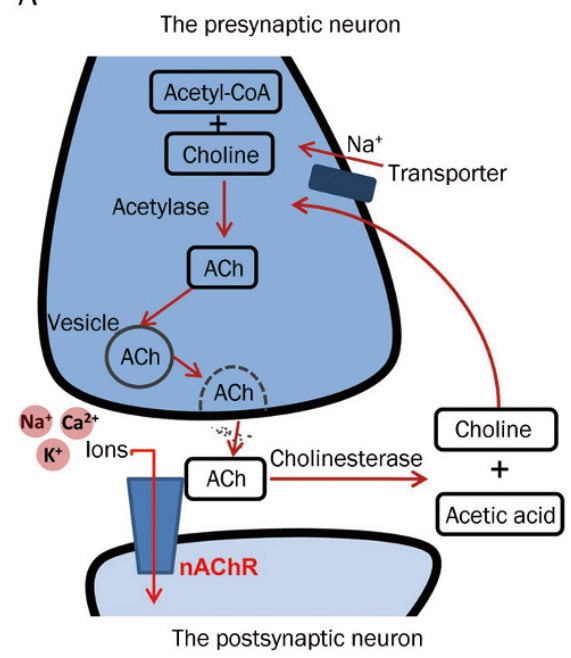

B

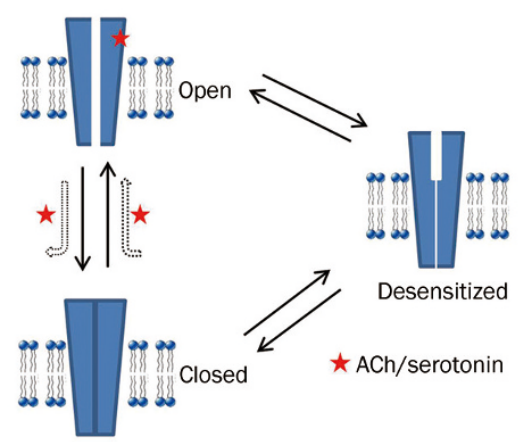

C

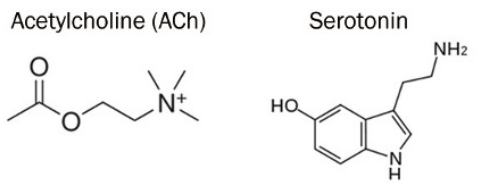

Figure 2. Mechanism of $n A C h R$ activation. (A) Acetylcholine (ACh) is synthesized, stored and released by cholinergic neurons. ACh is released from presynaptic neurons and binds to the nAChR of postsynaptic neurons to modulate the flow of ions across the cell membrane. (B) Three distinct functional states of the receptor exist: the closed, open and desensitized states; however, only the open state permits ion flux. (C) Chemical structures of the endogenous neurotransmitters ACh and serotonin (agonists).

cell membrane similarly to all cell-surface ligand-gated ion channels (Figure 2). In the nervous system, cholinergic stimulation mediated through nAChRs controls pathways such as transmitter release and cell sensitivity, which can influence physiological activity including sleep, anxiety, pain processing and cognitive functions ${ }^{[30-33]}$. A net influx of cations through the associated channel pore depolarizes the cell membrane and increases neuronal excitability. In particular, calcium entry through the nAChRs triggers a series of intracellular signaling cascades ${ }^{[23]}$.

On the molecular level, the activation of presynaptic $5-\mathrm{HT}_{3} \mathrm{Rs}$ also induces $\mathrm{Ca}^{2+}$ influx and modulates the vesicular release of various neurotransmitters and neuropeptides ${ }^{[34-36]}$. The activation of postsynaptic $5-\mathrm{HT}_{3} \mathrm{Rs}$ leads to depolarization by the opening of a channel permeable to $\mathrm{Ca}^{2+}$ as well as $\mathrm{Na}^{+}$and $\mathrm{K}^{+}$. On the systemic level, the $5-\mathrm{HT}_{3} \mathrm{Rs}$ in the CNS are involved in the integration of the vomiting reflex, pain processing, anxiety control and the reward system, while peripheral receptors participate in the regulation of autonomic functions and sensory transmission ${ }^{[37]}$. $5-\mathrm{HT}_{3} \mathrm{R}$ agonists lead to unpleasant feelings,

\begin{tabular}{|c|c|c|c|c|c|}
\hline \multicolumn{6}{|c|}{ nAChRs } \\
\hline \multicolumn{5}{|c|}{ Neuronal-type subunits } & \multirow{4}{*}{$\begin{array}{c}\text { Muscle-type subunits } \\
\text { IV } \\
\alpha 1, \beta 1, \delta, \gamma, \varepsilon\end{array}$} \\
\hline 1 & II & \multicolumn{3}{|c|}{ III } & \\
\hline \multirow{2}{*}{$\alpha 9, \alpha 10$} & \multirow{2}{*}{$\alpha 7, \alpha 8$} & 1 & 2 & 3 & \\
\hline & & $\alpha 2, \alpha 3, \alpha 4, \alpha 6$ & $\beta 2, \beta 4$ & $\beta 3, \alpha 5$ & \\
\hline \multicolumn{6}{|c|}{$5-\mathrm{HT}_{3} \mathrm{Rs}$} \\
\hline \multicolumn{2}{|c|}{ Homopentameric } & \multicolumn{4}{|c|}{ Heteropentameric } \\
\hline \multicolumn{2}{|c|}{$5-\mathrm{HT}_{3 \mathrm{~A}}$} & \multicolumn{4}{|c|}{$5-\mathrm{HT}_{3 \mathrm{~B}}, 5-\mathrm{HT}_{3 \mathrm{C}}, 5-\mathrm{HT}_{3 \mathrm{O}}, 5-\mathrm{HT}_{3 \mathrm{E}}$} \\
\hline
\end{tabular}

Figure 3. Subunits of the nAChRs and $5-\mathrm{HT}_{3} \mathrm{Rs}$. such as nausea and anxiety, thus are rarely used clinically. However, 5- $\mathrm{HT}_{3} \mathrm{R}$ antagonists are widely used for relieving chemotherapy-induced vomiting as well as radiotherapyinduced and post-operative nausea and vomiting. The $5-\mathrm{HT}_{3} \mathrm{Rs}$ also regulate gastrointestinal (GI) functions including secretion and motility, while their antagonists are effective in the management of post-infectious irritable bowel syndrome and severe diarrhea-predominant irritable bowel syndrome, although they present adverse gastrointestinal effects. More recently, involvement of the $5-\mathrm{HT}_{3} \mathrm{Rs}$ was found in psychiatric indications such as drug addiction, cognitive function, schizophrenia, satiety control, and the regulation of inflammatory and immune responses ${ }^{[38-40]}$.

The physiological processes regulated by the nAChRs and the $5-\mathrm{HT}_{3} \mathrm{Rs}$ are dependent on the specific ligand bound ${ }^{[41]}$. As illustrated in Figure 2, the binding of exogenous agonists to the orthosteric site substantially influences the transition rates between three distinct functional states of the receptor: the closed, open and desensitized states ${ }^{[42]}$. The rate constants between different functional states are highly dependent on the specific combination of subunits and the chemical nature of the agonist bound at the receptor ${ }^{[43]}$. The transition rates between the conformational states can also be modulated by endogenous or exogenous allosteric modulators ${ }^{[4]}$. Essentially, the conformational states of the receptor influence the activity of the target cells through the selective transportation of $\mathrm{Na}^{+}, \mathrm{K}^{+}$, and $\mathrm{Ca}^{2+}$ into cells to regulate various physiological processes ${ }^{[45]}$.

\section{Overall structure}

With the development of new technologies in structural biology, structural studies of ion channels have been progressing steadily, providing insights into the three-dimensional struc- 
ture of pentameric ligand-gated ion channels, especially the cation-selective channels (Figure 4). The first high-resolution cryo-EM structure $(4 \AA)$ of the nAChR from the Torpedo marmorata electric organ was reported in 2005 , revealing important functional and pharmacological characteristics of this receptor ${ }^{[46]}$. Based on the X-ray structures of the acetylcholine binding protein $(\mathrm{AChBP})$ and the serotonin binding protein (5-HTBP), an atomic model of the extracellular domain (ECD) of $\mathrm{nAChR}$ has been available for 15 years $^{[47-49]}$. AChBP and 5-HTBP are water-soluble proteins that have a high degree of sequence similarity to the ECD of the $\mathrm{nAChR}$ and the $5-\mathrm{HT}_{3} \mathrm{Rs}$, respectively. In 2008 and 2009, X-ray structures of two prokaryotic pLGICs, ELIC ${ }^{[50]}$ and GLIC ${ }^{[51]}$, were determined. Both are cation-selective ion channels that show high sequence and structure similarity to the nAChRs and the $5-\mathrm{HT}_{3} \mathrm{Rs}$. In 2011, the first X-ray structure of a eukaryotic pLGIC was determined $^{[52]}$. The crystal structure of the $\mathrm{GluCl}$ from Caenorhabditis elegans revealed an open conformation of the pLGIC. In 2014, two groups presented the X-ray structures of two mammalian pLGICs, the human $\mathrm{GABA}_{\mathrm{A}} \beta 3$ receptor ${ }^{[53]}$ and the mouse $5-\mathrm{HT}_{3 \mathrm{~A}}$ receptor ${ }^{[54]}$. These two structures offered the latest insights into the signaling mechanisms of pLGICs. Specifically, the serotonin $5-\mathrm{HT}_{3} \mathrm{R}$ and the $\mathrm{nAChR}$ are closest among the pLGICs and show very high sequence similarity (Figure 5A), suggesting that they may share structural characteristics and regulatory mechanisms. Notably, both the $\mathrm{GluCl}$ and $5-\mathrm{HT}_{3 \mathrm{~A}}$ structures were determined in complex with an antibody or a nanobody, which facilitates the crystallization of transmembrane channels.

Comparison of the aforementioned structures reveals that the overall structure appears to be conserved among the pLGICs, particularly the eukaryotic cation pLGICs, the nAChRs and the $5-\mathrm{HT}_{3}$ Rs. The different $\mathrm{nAChR}$ and $5-\mathrm{HT}_{3} \mathrm{R}$ subunits share a basic scaffold composed of an ECD, a fourtransmembrane helix domain (TMD), an intracellular domain (ICD) between the third and fourth transmembrane helix and a short extracellular C-terminus. The receptors are therefore built from modular units with an extracellular domain con- taining the agonist/antagonist binding pocket, a transmembrane domain containing the allosteric modulatory sites and a large cytoplasmic domain involved in receptor trafficking and regulation (Figure 5B and 5C). Comparison of available structures revealed that the overall structure of cation-selective pLGICs (nAChRs and $5-\mathrm{HT}_{3} \mathrm{Rs}$ ) is different from anion-selective pLGICs $\left(\mathrm{GABA}_{\mathrm{A}} \mathrm{Rs}\right.$ and GlyRs), with the presence of a relatively large ICD that may play an important role in cation conduction.

\section{Extracellular domain and binding pocket}

The organization of the ligand binding pocket of the nAChRs and the $5-\mathrm{HT}_{3} \mathrm{Rs}$ has been confirmed by many structures. A major step toward this achievement was the determination of the high-resolution crystal structures of the soluble proteins that bind ACh or serotonin, AChBP and 5-HTBP, respectively. These soluble proteins share key structural elements with the ECDs of nAChRs and $5-\mathrm{HT}_{3} \mathrm{Rs}$, which display similar ligand binding signatures, and their respective structures have become models for the ECDs of the nAChR and the 5-HT ${ }_{3}$. The 5-HTBP was engineered from the weakly 5-HT-binding AChBP by a series of mutations. Single-point mutations of the $\mathrm{nAChR}$ and the $5-\mathrm{HT}_{3} \mathrm{R}$ are sufficient to switch agonist actions of serotonin and acetylcholine, respectively, to antagonists ${ }^{[5,56]}$. These mutations confirm the ligand recognition sites and reveal that the $\mathrm{nAChR}$ and the $5-\mathrm{HT}_{3} \mathrm{R}$ use the same structural elements for ligand binding.

Based on the modeling of the pentameric structure of AChBP, each nAChR ECD monomer consists of an N-terminal $\alpha$-helix and a core of ten $\beta$-strands that form an $\alpha \beta$-sandwich structure. The inner $\beta$-sheet is formed by $\beta 1, \beta 2, \beta 3, \beta 5, \beta 6$ and $\beta 8$ and the outer $\beta$-sheet by $\beta 4, \beta 7, \beta 9$ and $\beta 10$. The Nand C-termini are located at the top and bottom of the pentamer fold, respectively. The C-terminus of $\beta 10$ is connected to the N-terminus of TM1. The linker between strands $\beta 6$ and $\beta 7$ forms the signature Cys-loop found in all members of the Cys-loop receptor (CLR) family. This Cys-loop is close to the transmembrane domain and may play a role in the propaga-

2005-2014

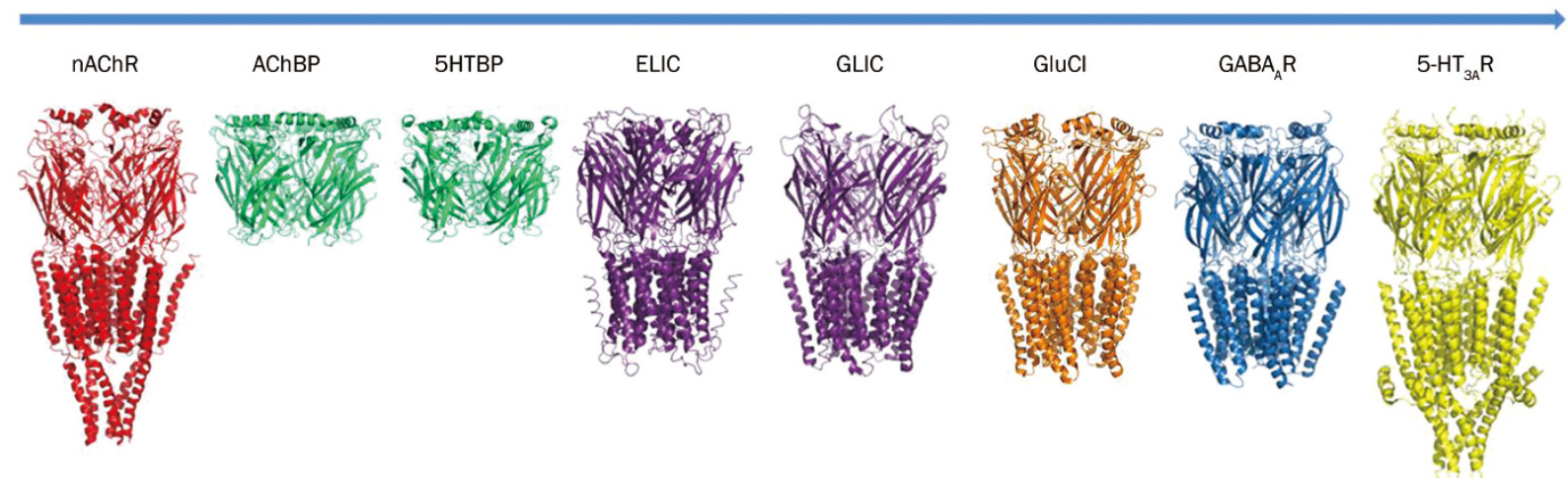

Figure 4. Overview of the published pLGIC structures (2005-2014). From left to right: the electron-microscopic structure of the Torpedo marmorata $\mathrm{nAChR}$ and the X-ray structures of ACh Binding Protein (AChBP), 5-HT Binding Protein (5-HTBP), the Erwinia chrysanthemi ligand-gated ion channel (ELIC), the Gloeobacter violaceus ligand-gated ion channel (GLIC), the Caenorhabditis elegans glutamate-gated chloride channel (GluCl), the human GABA receptor $\left(\mathrm{GABA}_{A} \mathrm{R}\right)$, and the mouse serotonin $5-\mathrm{HT}_{3 \mathrm{~A}}$ receptor $\left(5-\mathrm{HT}_{3 A} \mathrm{R}\right)$. 
A

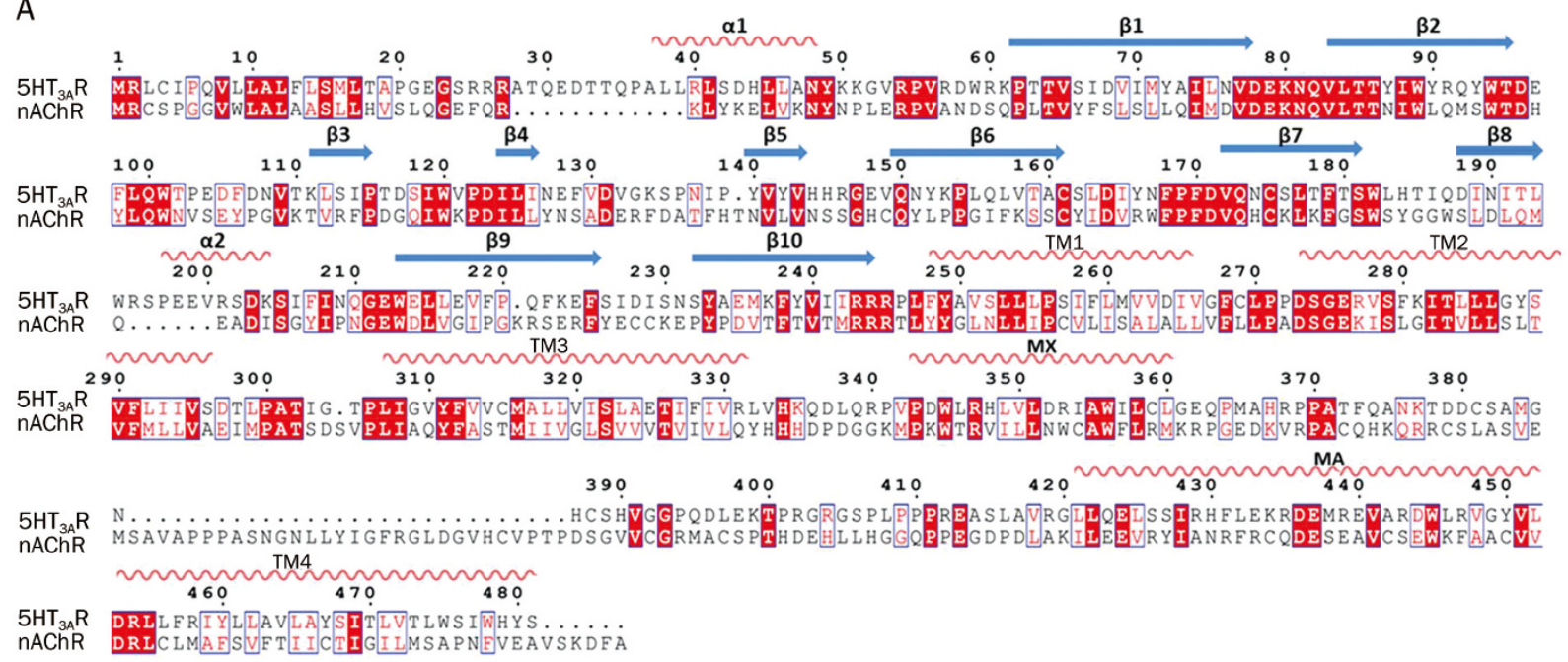

B

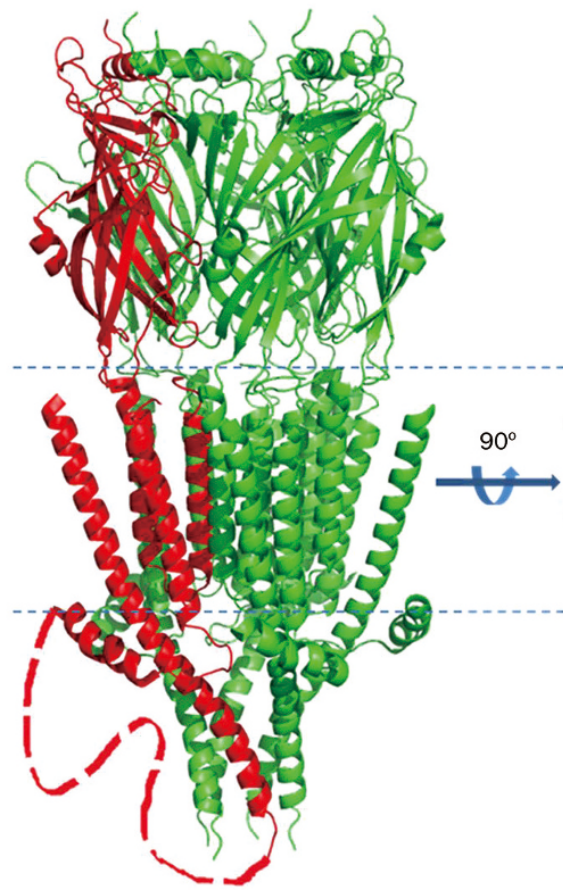

C

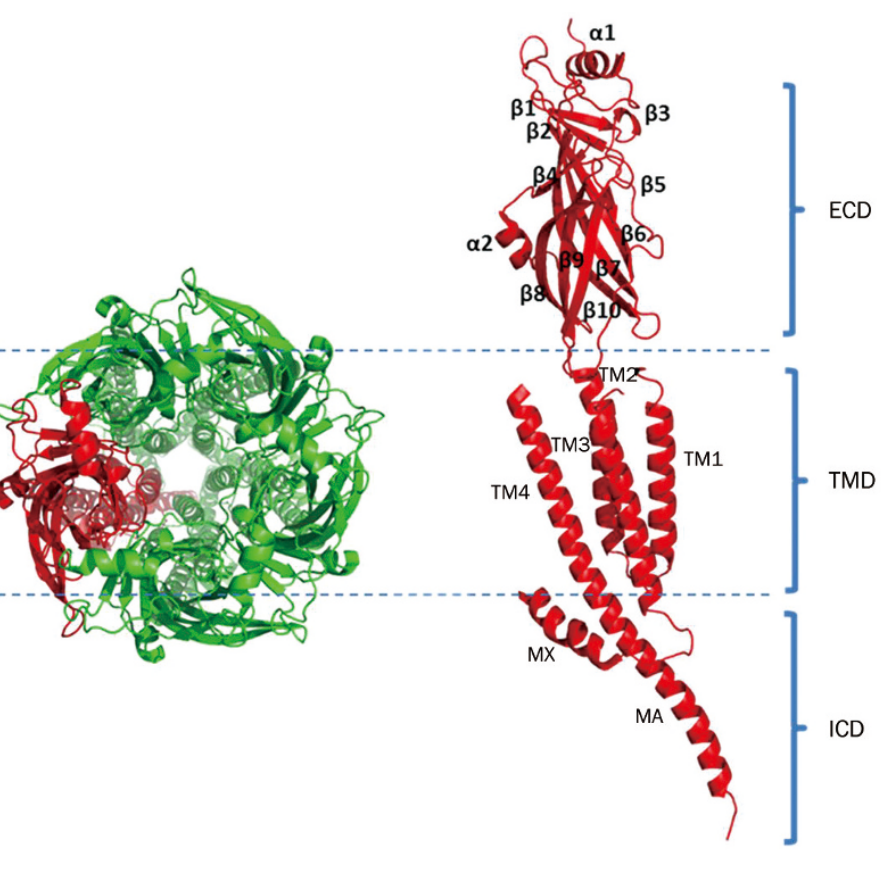

Figure 5. Basic structure of the cation-selective pentameric ligand-gated ion channels. (A) Structure-based sequence alignment of the human nAChR and the mouse $5-\mathrm{HT}_{3 \mathrm{~A}}$ receptor. (B) Schematic view of the X-ray structure of the 5- $\mathrm{HT}_{3}$ receptor (side and top view). The dashed line represents a long fragment of the cytoplasmic loop (shown only for one front subunit) that was not resolved in the X-ray structure. (C) Structure of one subunit of the $5-\mathrm{HT}_{3} \mathrm{R}$ model. A side view showing the extracellular domains (Cys-loop, $\alpha 1-2$ and $\beta 1-10$ ), the transmembrane domains (TMD, TM1-4), and the intracellular domain (ICD).

tion of conformational changes from the ECD to the TMD ${ }^{[57]}$ (Figure 5C). High resolution crystal structures of AChBPs in complex with several nicotinic receptor ligands revealed the orthosteric binding sites for agonists and antagonists in detail. The ligand binding sites are situated at the interface between two neighboring subunits, the principal (ie, two constant a-subunits) and the complementary non-a subunits (Figure 6A). Residues from loops A-C of the principal subunit as well as $\beta$-strands $\mathrm{D} / \mathrm{E}$ and loop $\mathrm{F}$ of the complementary subunit contribute to ligand recognition. The key residues involved in ACh binding are Trp86, Tyr93 (loop A), Trp149, Gly153 (loop B), Tyr190, Cys192, Cys193, and Tyr198 (loop C) from the principal subunit, and Trp55, Asp57 ( $\beta$ strand D), Leu109, Arg111, Thr117, Leu119 ( $\beta$ strand E), Asp174, and Glu176 (loop F) from the complementary subunit ${ }^{[58]}$ (Figure 6A). Although the subunits of mammalian pLGIC are generally conserved, these pocket amino acids are not identical in nAChRs and 5- $\mathrm{HT}_{3} \mathrm{Rs}$, providing a basis of their ligand binding selectivity. 
Transmembrane domain and allosteric modulatory sites The transmembrane domain of the nAChRs and the $5-\mathrm{HT}_{3} \mathrm{Rs}$ is composed of four helices, TM1 to TM4, which perpendicularly span through the membrane bilayer. The TM1, TM2, and TM3 helices are a closely packed bundle and are ordered in two concentric circles. The assembly of the five TM2 helices forms the inner circle and the ion channel pore, which is an important segment of the ion conduction pathway. Transmembrane helices TM1 and TM3 form the outer circle that stabilizes the pore. TM4, located at the periphery of the transmembrane domain, is relatively loosely packed ${ }^{[59-61]}$ (Figure 6B).

The transmembrane domains of the nAChRs and the $5-\mathrm{HT}_{3} \mathrm{Rs}$ contain binding sites for various allosteric modulators. General anesthetics are small hydrophobic compounds that allosterically inhibit the receptors by binding to a small cavity formed by specific residues located between TM3 and TM4. Crystal structures of the GluCl in complex with a hydrophobic ligand enabled visualization of this allosteric binding site. These allosteric modulators act by binding to regions called allosteric sites, which are separate from the ACh/ serotonin binding sites (orthosteric sites) (Figure 6B). The allosteric modulators have either positive (positive allosteric modulators, PAMs) or negative (negative allosteric modulators, NAMs) effects ${ }^{[62]}$. PAMs/NAMs typically exhibit little intrinsic activity but provide selective potentiation/inhibition of physiological activity without directly interfering with the ongoing signaling processes. Ivermectin, 5-hydroxyindole, NS-1738, SB-206553 and PNU-120596 have been reported to function as PAMs at the $n \mathrm{AChRs}^{[63]}$. The development of PAMs is of great significance, as they may effectively avoid receptor desensitization processes.

\section{Channel activation}

The overall architecture of the channel complex assembly reveals that the ligand binding site in ECD is far above the channel pore in the TMD region (Figure 4). The mechanism of how ligand binding at the ECD can control (by gating) the opening and closing of the distal channel pore at the TMD is very intriguing. At their resting states, the channels of the $\mathrm{nAChRs}$ and the $5-\mathrm{HT}_{3} \mathrm{Rs}$ are closed. The binding of agonist to the ECD triggers rapid conformational changes, which leads to the opening of the transmembrane pore, a process referred to as gating isomerization.

The crystal structures of a chimeric a7 nicotinic recep-
A

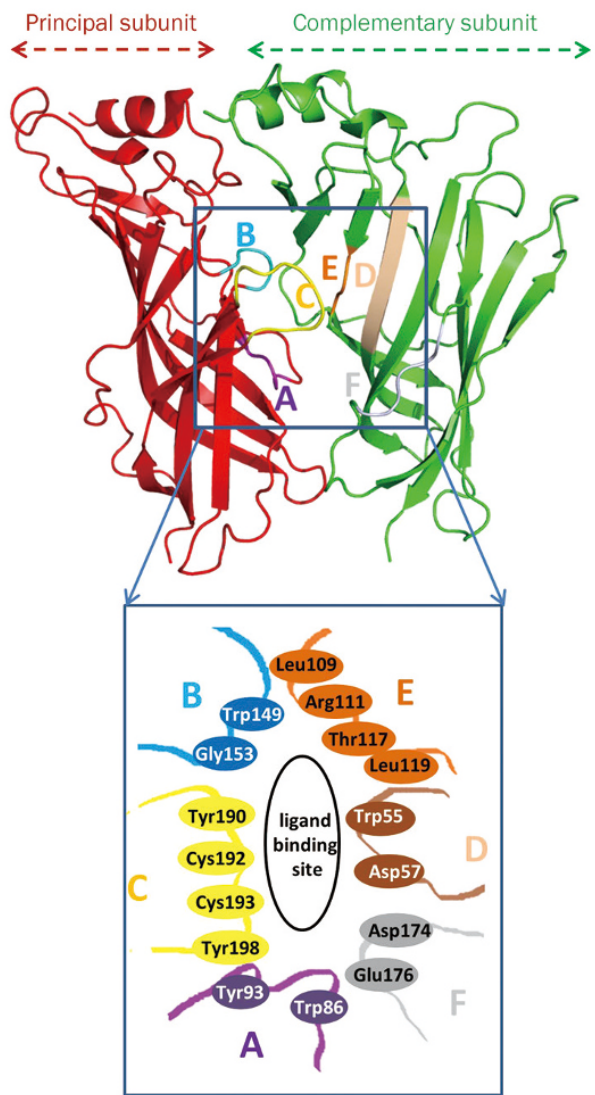

B

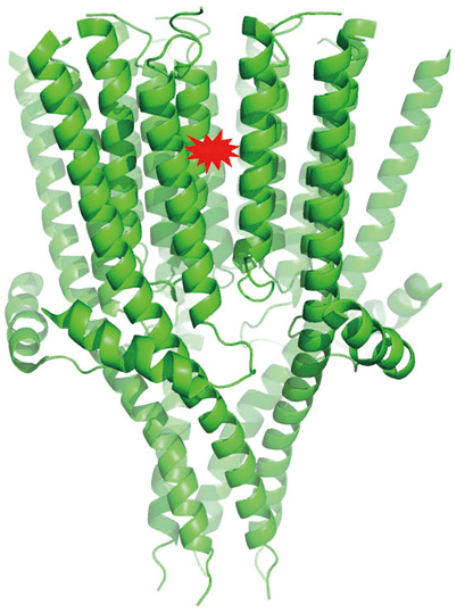

Allosteric modulatory site
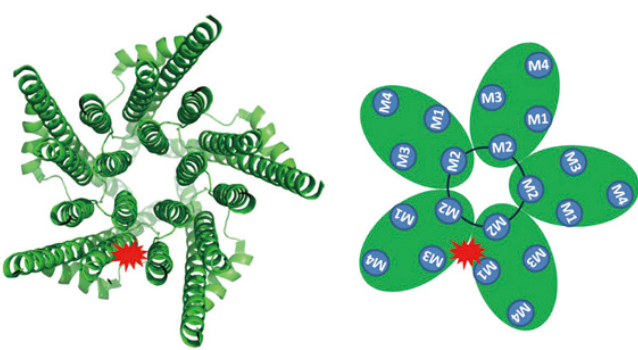

Figure 6. Structure of the ligand binding and allosteric modulatory sites. (A) Close-up view of a ligand binding site showing the amino acid residues in the loops that participate in its formation. Loops $\mathrm{A}, \mathrm{B}$, and $\mathrm{C}$ are provided by the principal subunit and loops $\mathrm{D}$, $\mathrm{E}$, and $\mathrm{F}$ by the complementary subunit. (B) The X-ray structure of the transmembrane domain of the $5-\mathrm{HT}_{3}$ receptor (side/top view and schematic chart). Each subunit of the TMD contributes four helices (TM1-4), which approach one another at the intracellular membrane surface, creating a tapered central pore. View of the side of the TMD showing a potential binding site for allosteric modulators (marked by a red asterisk). The intersubunit allosteric modulatory site is modeled based on the crystal structure of ivermectin bound GluCl. The site is located in the transmembrane domain between the four transmembrane segments (TM1-4). 
tor ECD with its agonist epibatidine ${ }^{[64]}$ and its antagonist a-bungarotoxin ${ }^{[65]}$ enabled observation of this process. Structural comparison of the agonist- and antagonist-bound conformations revealed a large movement of loop $\mathrm{C}$, which was also observed in a similar comparison of the agonist- and antagonist-bound 5-HTBP structures ${ }^{[66]}$. By further investigation of these structures, a twisting and blooming model was initially suggested to be directly involved in ion channel activation (Figure 7A). The relatively small conformational changes at the ligand binding site suggest a highly efficient gating mechanism.

Structures of the open state GLIC and the closed state ELIC elucidate how the conformational changes induced by agonist binding are propagated from the ECD to the TMD (Figure

A
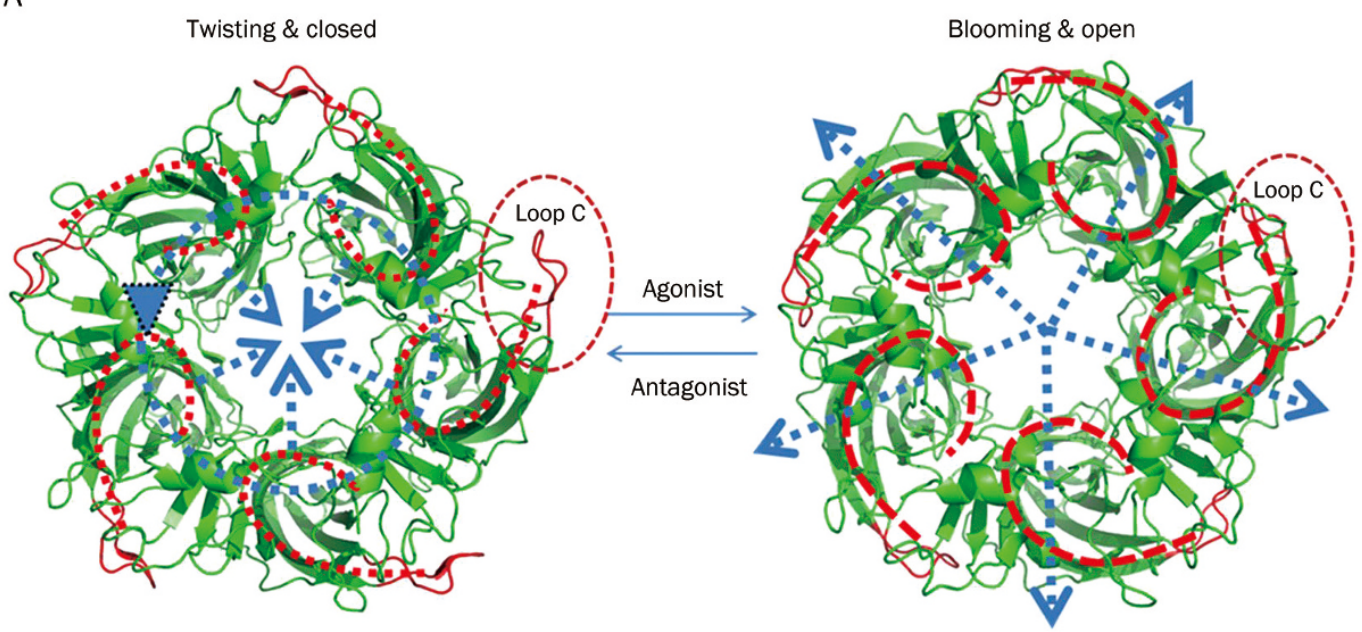

B

C

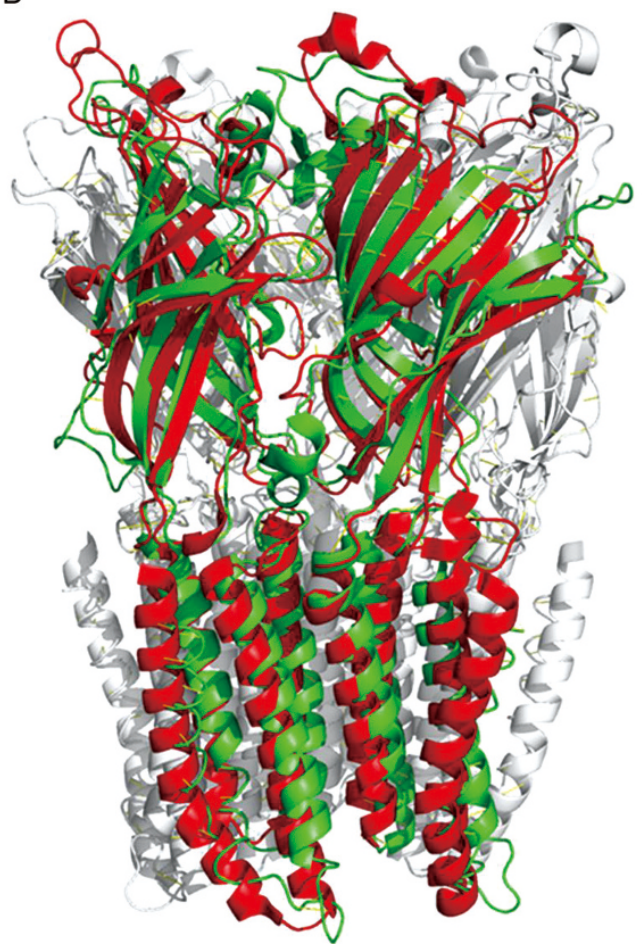

D
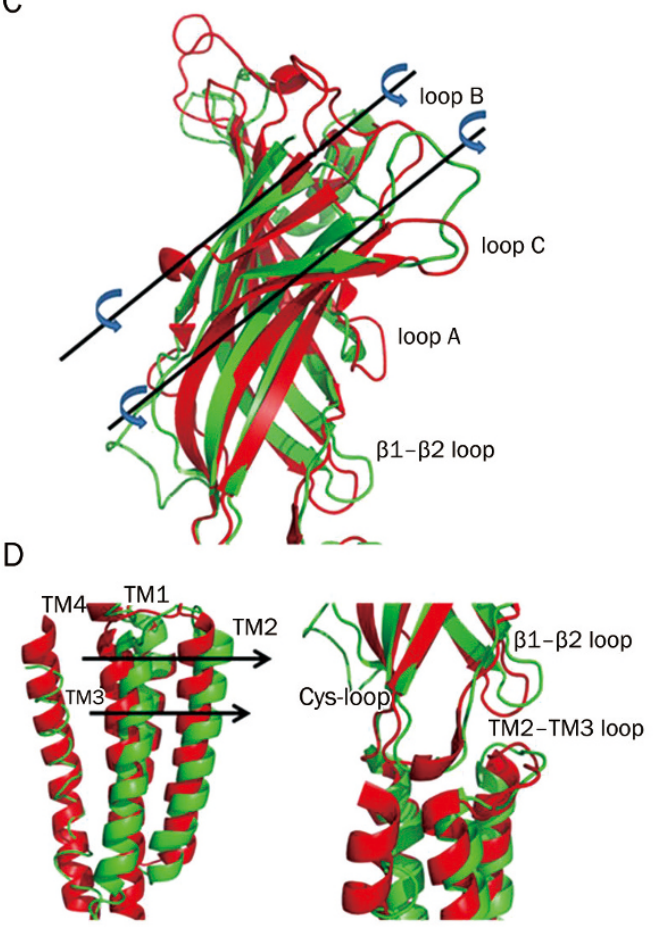

Figure 7. The proposed gating mechanism of the receptors. (A) The twisting and blooming model. On top, the twisting and blooming transition is shown. The conformation of the open and closed states is captured by the crystal structures of the ligand binding domain of a pentameric $\alpha 7$ nicotinic receptor chimera with its agonist epibatidine (right) and its antagonist $\alpha$-bungarotoxin (left). When agonist is bound, loop $\mathrm{C}$ is repositioned towards the structural subunit to cap the agonist-binding site, and it extends away from the agonist binding pocket when the site is occupied by an antagonist. The blue dashed arrows illustrate the direction of the twisting and blooming. (B) Open GLIC and closed ELIC structure comparison. The two subunits in the foreground are colored green for GLIC and red for ELIC, and the other subunits are shown in grey. (C) A rotation of the extracellular domain. (D) Closeup view of the TMD and the interface between the ECD and the TMD. Concerted downward motion of the $\beta 1-\beta 2$ loop and outward motion of the TM2TM3 segment causes pore opening. 
7B). The proposed model of gating is a stepwise isomerization process that starts from the orthosteric binding site (loops A, $B$, and $C$ ) (Figure $7 C$ ), then propagates to the ECD/TMD interface ( $\beta 1-\beta 2$ loop and Cys-loop) via a rigid-body rearrangement of the extracellular $\beta$-sandwiches, which in turn induces outward movement of the loop between transmembrane helices TM2 and TM3, ultimately resulting in the opening of the gate that is formed by the TM2 helix (Figure 7D). This structural rearrangement was best described as a concerted opposite-twist rotation of the ECD relative to the TMD around the five-fold symmetry axis.

In 2011 and 2014, two structures of the C. elegans GluCl were published. One structure is in complex with the allosteric partial agonist ivermectin, which provided insights into the structure of a potentially open state, and the other is the apo state, a 1-palmitoyl-2-oleoyl-sn-glycero-3-phosphocholine (POPC)bound conformation ${ }^{[67]}$. These two structures of eukaryotic Cys-loop receptors further answered questions regarding the mechanism of channel opening and closing. The TM2-TM3 loop can shift away from the ion channel pore, as visualized by the movement of Pro268 from the TM2-TM3 loop passing beneath Val45 on the $\beta 1-\beta 2$ loop. The closed pore is most constricted at Leu254 on TM2, suggesting that Leu254 forms the shut gate of the ion channel pore (Figure 8A). Further-

A
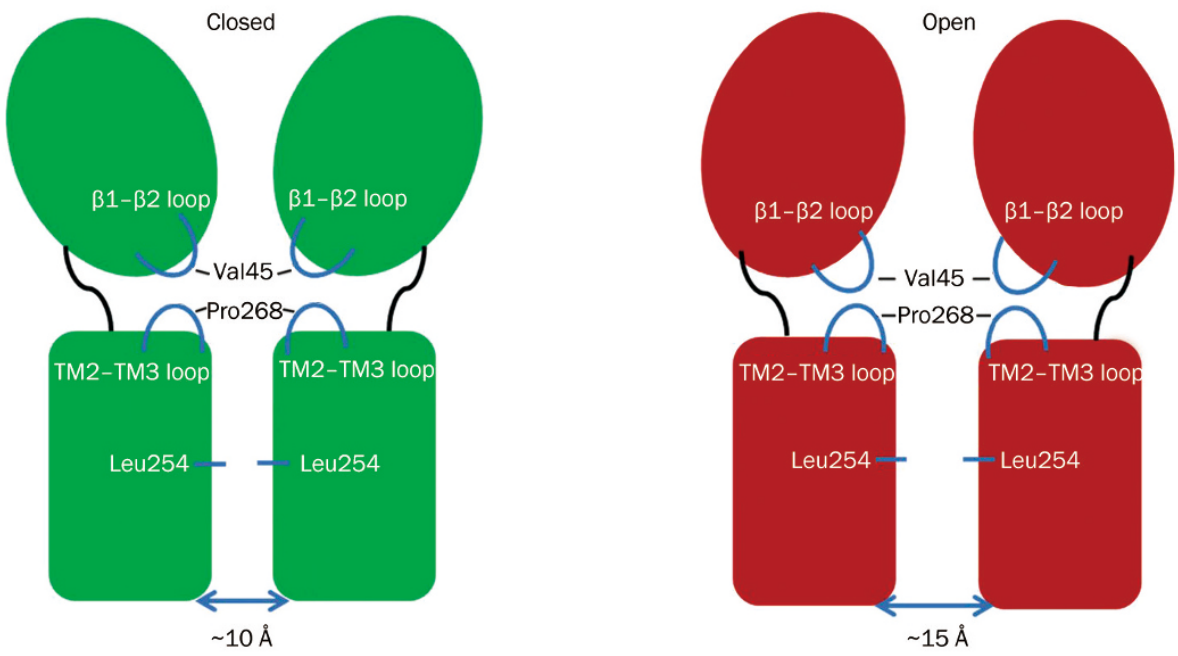

B

$\begin{array}{ll}\text { GluCl } & 28 \\ \text { GlyR } & 35 \\ \text { GABAR } & 4 \\ \text { 5HT }_{3} \mathrm{R} & 37 \\ \text { nAChR } & 28 \\ \text { Consensus } & \end{array}$

GluCl

GlyR

GABAR

$5 \mathrm{HT}_{3} \mathrm{R}$

nAChR

Consensus

\section{GluCl}

GlyR

GABAR

$5 \mathrm{HT}_{3} \mathrm{R}$

nAChR

Consensus

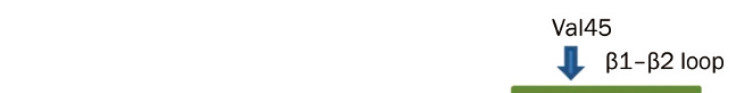

28

35

40

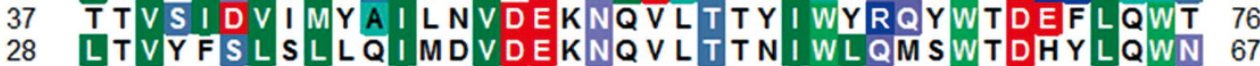

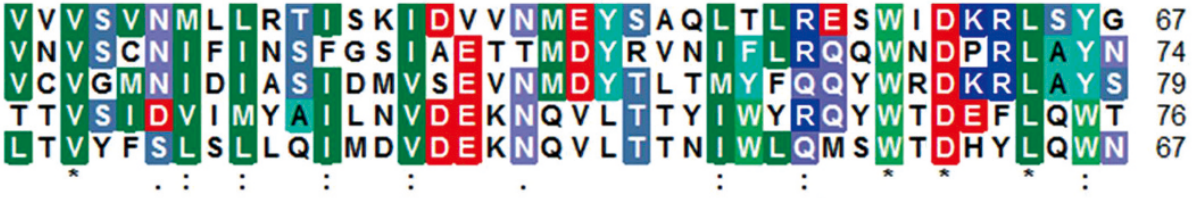

Leu254

1

TM2

225 CMLVI V SWV S FWFDR TA I PARVTLGVTTLLTMTAQSAGIN 264

230 L L I V I L S W I S FW I NMDA A P AR VGL C I T T V L T M T T Q S S G S R 269

234 I L I T I L SWV S FW I NYDA S A AR V A L G I T T V L TMT T I N T HLR 273

232 I F L M V VD I VGF CLPPDSG - ER V S F K I TLL LG Y S F L I I V S 270

219 V L I S A L A L L V F L LP AD SG - EK I S L G I TV L L S L TV F M LVA 257

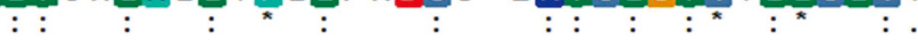

Pro268

ᄀ тМ2-тМ3 lоoр

265 SQLPPVSY - I KA I DVWI ACMTFIFCALLEFALVNHI AN - 302

270 A S L P KV S Y - VKA I D I WMA VCLLFV F A L L E A A V N F V S R Q 308

274 ETLPK I P Y - V KA I DMY LMGCFV F F LA L LEYAFVNY I F F S 312

271 D T L P A T A I G T P L I GVYF V VC MA L L V I S L AE T I F I V R L V HK 310

258 EIMPA TSD SVP L I A Q F A S TM I I VGLSVVV T I VLQY H H 297

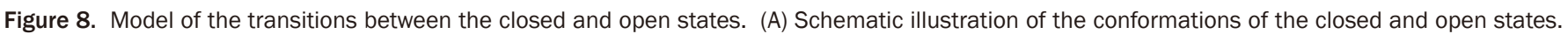

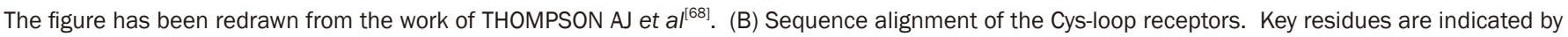
the arrow. GluCl: C. elegans GluCl $\alpha$; GlyR: human glycine $\alpha 1$; GABAR: human GABAß3; 5-HT ${ }_{3} \mathrm{R}$ : mouse 5-HT 3 ; and nAChR: human nAChR $\alpha 7$. 
more, Pro268 and Leu254 are strictly conserved throughout the family of Cys-loop receptors (Figure 8B), and they could play a similar role in the opening and closing of nAChRs and $5-\mathrm{HT}_{3} \mathrm{Rs}$.

Taken together, the available structures present a common ligand gating mechanism, where ligand binding at the ECD induces a stepwise isomerization of the subunit interface, which is then propagated to the ECD-TMD interface, resulting in tilting of the TM2 helix that leads to the opening of the channel pore (Figure 7). Interestingly, the allosteric ligand binding site is located in the TMD that is close to the channel pore but far from the ligand binding site in the ECD. We speculate that PAMs and NAMs modulate the channel activities by reducing (PAM) or increasing (NAM) the energy barrier of channel opening.

\section{Cation selectivity and ion conduction in the ICD}

The cation selectivity of $\mathrm{nAChRs}$ and $5-\mathrm{HT}_{3} \mathrm{Rs}$ is determined by the charge properties along the ion permeation pathway (Figure 9A). The width of the extracellular vestibule is approximately $20 \AA$, which is appropriate for electrostatic interactions between the charged groups lining the vestibule and for cations to pass through. The charge below the conserved constriction (D105 in the mouse $5-\mathrm{HT}_{3 \mathrm{~A}}$ receptor) is predominantly negative, thus providing an environment to stabilize cations and increase the local concentrations of cations within the lower part of the ECD vestibule. From the bottom of the ECD, cations enter the pore lined by the TM2 helices, and the residues that form the pore lumen surface are almost identical in $\mathrm{nAChRs}$ and $5-\mathrm{HT}_{3} \mathrm{Rs}$ (Figure 9B). The upper portion of the pore is a hydrophobic constriction that may serve as the chan- nel gate, while the lower half contains two polar rings that are negatively charged. The negatively charged residues at the bottom of the transmembrane pore may facilitate cations entry into the intracellular vestibule, which has been identified as a major determinant of ionic selectivity and conductance ${ }^{[68-70]}$ (Figure 9B).

The intracellular vestibule is lined by the post-TM3 loop and the C-terminal amphipathic membrane-associated (MA) helices, which were revealed in the EM structure of the Torpedo acetylcholine receptor and the X-ray structure of the mouse serotonin $5-\mathrm{HT}_{3 \mathrm{~A}}$ receptor. The structure of the Torpedo acetylcholine receptor revealed that there are solvent-exposed channels in the upper part of the MA helices for ion exit and entry. The corresponding solvent-exposed channels appear to be blocked by the post-TM3 loops in the mouse serotonin $5-\mathrm{HT}_{3 \mathrm{~A}}$ receptor structure. Moreover, in the $5-\mathrm{HT}_{3 \mathrm{~A}}$ structure, the lower part of the MA helical bundle forms a central channel that is too narrow for ions to pass through unless conformational changes occur. To confirm the exit or entry of ions in the ICD, the conformation of intact receptors in the active state requires further investigation. However, two possible pathways for ion conductance in the ICD are shown in Figure 10. Mutagenesis studies support that the upper channels, not the lower MA helix, are involved in ion conductance ${ }^{[71]}$.

\section{Diseases and drug discovery}

In parallel with advances in our understanding of the pharmacology of $\mathrm{nAChRs}$ and $5-\mathrm{HT}_{3} \mathrm{Rs}$, there has been an increasing interest in these receptors as potential drug targets for a number of psychiatric, neurological, and peripheral disorders ${ }^{[72]}$ (Table 1). During the past 10 years, a growing number of
A

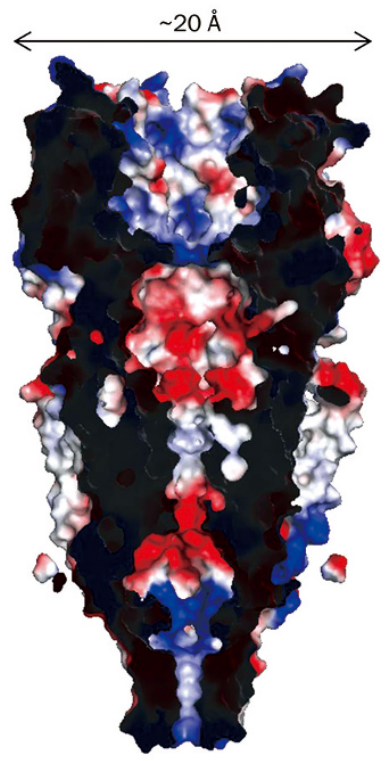

$-69 \mathrm{kTe}^{-1}$

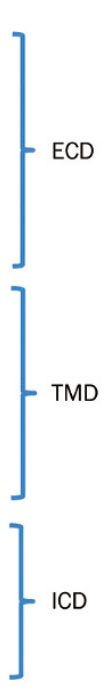

$+69 \mathrm{kTe}^{-1}$
B

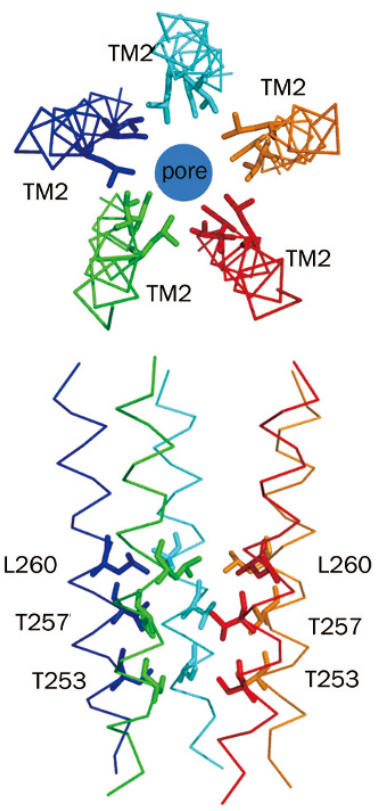

Figure 9. Cation-selectivity. (A) The front of the mouse 5- $\mathrm{HT}_{3}$ receptor is cut away to reveal the interior surface of the pore, colored by electrostatic potential from $-69 \mathrm{kTe}^{-1}$ to $15 \mathrm{kTe}^{-1}$ (red to blue). (B) The side chains of key pore-lining residues, numbered according to their position in the TM2 helix. 
Table 1. Clinical development pipeline of nAChR and $5-\mathrm{HT}_{3} \mathrm{R}$ ligands.

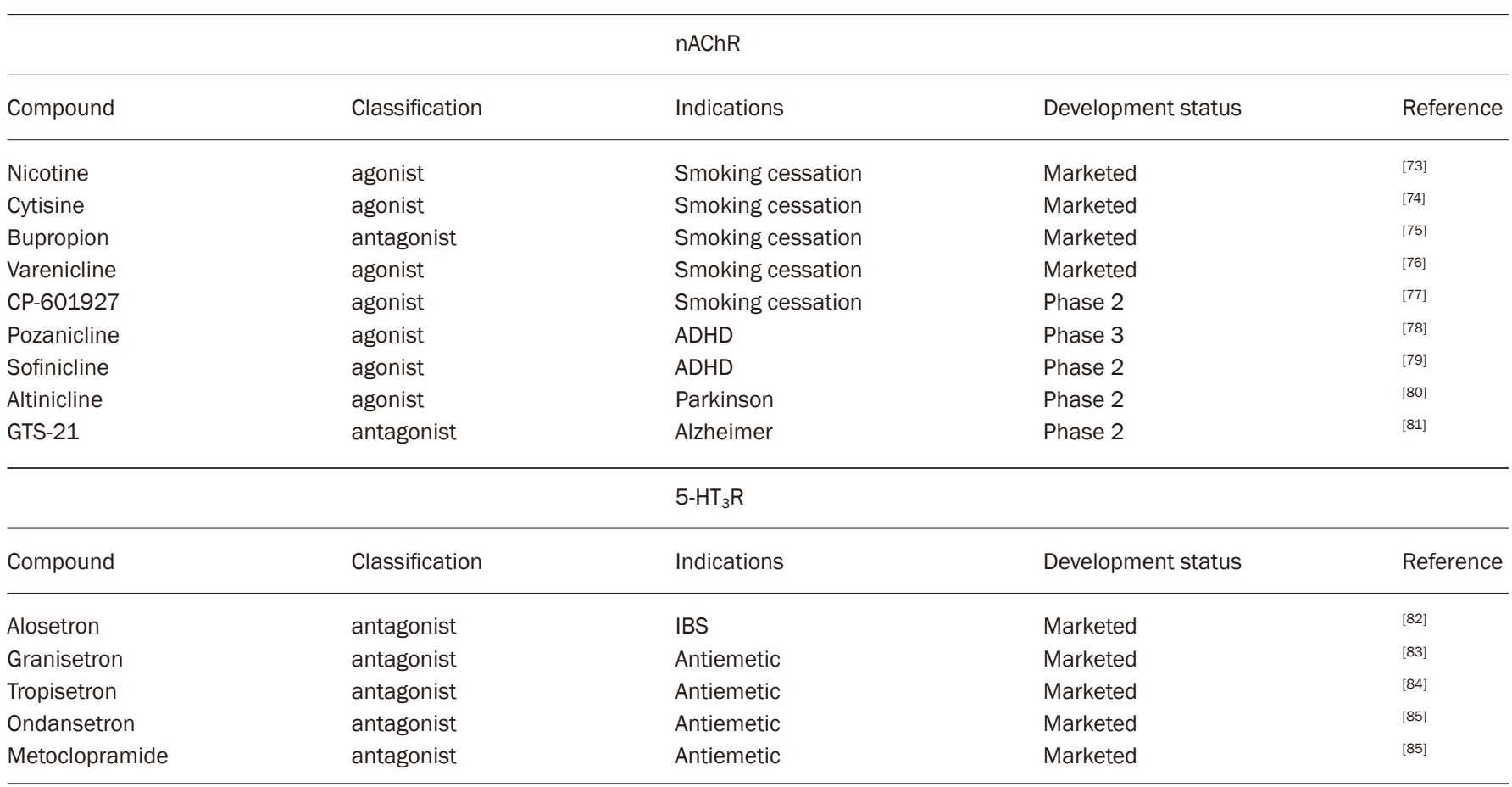

ADHD, attention deficit hyperactivity disorder; IBS, irritable bowel syndrome.

ligands have been discovered that selectively alter the function of $\mathrm{nAChR}$ and $5-\mathrm{HT}_{3} \mathrm{R}$ subtypes, which have been characterized in a variety of expression systems, native cells, tissues and model animals ${ }^{[86]}$. In most cases, these compounds have been designed to be agonists, antagonists, or allosteric modulators for treating a specific disease. The main obstacles in the development of new compounds are unsatisfactory clinical efficacy and a high incidence of adverse events with a narrow therapeutic window. The most common side effects associated with $\mathrm{nAChR}$ and $5-\mathrm{HT}_{3} \mathrm{R}$ ligands occur in the gastrointes-
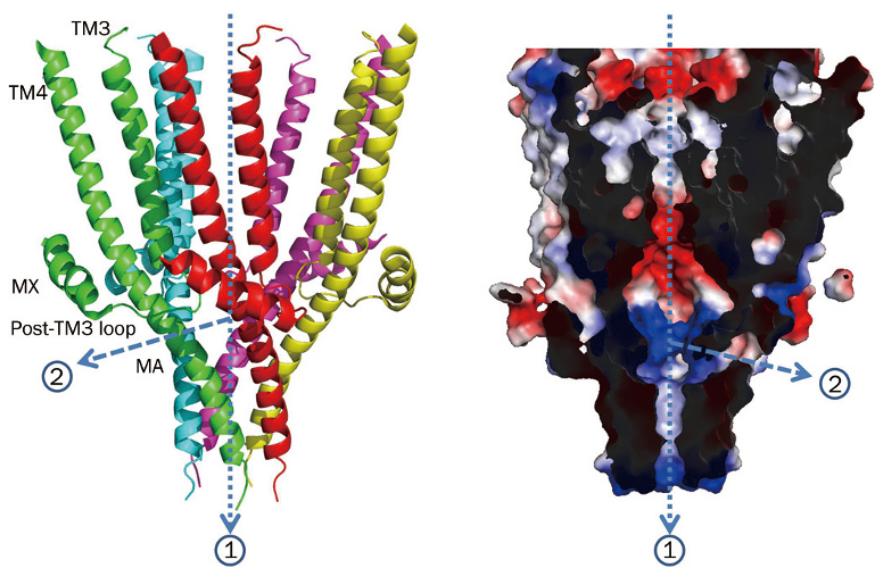

Figure 10. Two possible modes of ion conduction in the ICD of the cationselective pLGIC: through the enlarged tunnel surrounded by the lower MA helices (1) or through the open windows (2) between the upper MA helices. tinal and central nervous systems. Despite these challenges, several drugs targeting the nAChRs and the $5-\mathrm{HT}_{3} \mathrm{Rs}$ have moved beyond clinical trial stages into medical application. Further structural studies of the nAChR and the $5-\mathrm{HT}_{3} \mathrm{R}$ will enhance the discovery of small molecule modulators of these two important receptors for therapeutic purposes.

\section{Conclusions and future directions}

In the past few decades, the $\mathrm{nAChRs}$ and the $5-\mathrm{HT}_{3} \mathrm{Rs}$ have been a focus of intense research. These efforts have greatly increased our understanding of the structural and functional basis of these two important ion channels, which is predominantly a result of technological advances in high-throughput screening and crystallization. Significant progress has also been made in recent years on receptor expression, distribution, and physiological function. However, the molecular mechanisms of cation selectivity, channel gating and interaction with downstream effector proteins remain to be elucidated through the determination and analysis of high resolution structures of these two channels in various conformational states.

Additionally, the nAChRs and the 5- $\mathrm{HT}_{3} \mathrm{Rs}$ are implicated in a range of neurological and psychiatric diseases. Significant drug discovery efforts have been devoted to these two receptors and several promising ligands targeting these two receptors have been developed over the past few years. However, the discovery of potent ligands that interact more selectively with the nAChRs and the $5-\mathrm{HT}_{3} \mathrm{Rs}$ and display minimal or no side effects is urgent. To avoid receptor desensitization and to increase ligand efficacy and selectivity, the development of 
PAMs has garnered significant interest.

Taken together, the structural information of cation-selective pentameric ligand-gated ion channels has been steadily improved because of the increasing availability of relevant structures over the past decade. These advancements have also led to a better understanding of the disorders and physiological functions associated with $\mathrm{nAChRs}$ and $5-\mathrm{HT}_{3} \mathrm{Rs}$, and they have started to provide a rational basis for ligand design and drug discovery. With recent technological breakthroughs in structure determination by cryo-EM and femtosecond X-ray laser, one would expect that structural information of these two receptors in various functional states ( $e g$, closed and open states) will provide direct mechanisms of ligand gating and activation and further promote structure-based design of specific ligands to modulate their physiological function and modify the disease states. The recent expression and purification of the $\mathrm{nAChR}$ and the human $5-\mathrm{HT}_{3 \mathrm{~A}}$ receptor will further facilitate the structural studies of these two receptors in various conformational states ${ }^{[87,88]}$.

\section{Acknowledgements}

This work was supported in part by the Jay and Betty Van Andel Foundation as well as by Ministry of Science and Technology (China) grants 2012ZX09301001, 2012CB910403, 2013CB910600, XDB08020303, and 2013ZX09507001.

\section{References}

1 Fucile S. $\mathrm{Ca}^{2+}$ permeability of nicotinic acetylcholine receptors. Cell Calcium 2004; 35: 1-8.

2 Lambert JJ, Peters JA, Hales TG, Dempster J. The properties of 5- $\mathrm{HT}_{3}$ receptors in clonal cell lines studied by patch-clamp techniques. $\mathrm{Br} \mathrm{J}$ Pharmacol 1989; 97: 27-40.

3 Yang J. Ion permeation through 5-hydroxytryptamine-gated channels in neuroblastoma N18 cells. J Gen Physiol 1990; 96: 1177-98.

4 Role LW, Berg DK. Nicotinic receptors in the development and modulation of CNS synapses. Neuron 1996; 16: 1077-85.

5 Paterson D, Nordberg A. Neuronal nicotinic receptors in the human brain. Prog Neurobiol 2000; 61: 75-111.

6 Barnes JM, Barnes NM, Costall B, Ironside JW, Naylor RJ. Identification and characterisation of 5-hydroxytryptamine 3 recognition sites in human brain tissue. J Neurochem 1989; 53: 1787-93.

7 Michel K, Zeller F, Langer R, Nekarda H, Kruger D, Dover TJ, et al. Serotonin excites neurons in the human submucous plexus via $5-\mathrm{HT}_{3}$ receptors. Gastroenterology 2005; 128: 1317-26.

8 Engelman HS, MacDermott AB. Presynaptic ionotropic receptors and control of transmitter release. Nat Rev Neurosci 2004; 5: 135-45.

9 Liu Y, Zeng X, Hui Y, Zhu C, Wu J, Taylor DH, et al. Activation of alpha7 nicotinic acetylcholine receptors protects astrocytes against oxidative stress-induced apoptosis: implications for Parkinson's disease. Neuropharmacology 2015; 91: 87-96.

10 Fan $H$, Gu R, Wei D. The alpha7 nAChR selective agonists as drug candidates for Alzheimer's disease. Adv Exp Med Biol 2015; 827: 353-65.

11 Rowe AR, Mercer L, Casetti V, Sendt KV, Giaroli G, Shergill SS, et al. Dementia praecox redux: a systematic review of the nicotinic receptor as a target for cognitive symptoms of schizophrenia. J Psychopharmacol 2015; 29: 197-211.

12 Gregory RE, Ettinger DS. 5- $\mathrm{HT}_{3}$ receptor antagonists for the preven- tion of chemotherapy-induced nausea and vomiting. A comparison of their pharmacology and clinical efficacy. Drugs 1998; 55: 173-89.

13 Greenshaw AJ. Behavioural pharmacology of $5-\mathrm{HT}_{3}$ receptor antagonists: a critical update on therapeutic potential. Trends Pharmacol Sci 1993; 14: 265-70.

14 Leeser J, Lip H. Prevention of postoperative nausea and vomiting using ondansetron, a new, selective, $5-\mathrm{HT}_{3}$ receptor antagonist. Anesth Analg 1991; 72: 751-5.

15 Grant KA. The role of $5-\mathrm{HT}_{3}$ receptors in drug dependence. Drug Alcohol Depend 1995; 38: 155-71.

16 Jones S, Sudweeks S, Yakel JL. Nicotinic receptors in the brain: correlating physiology with function. Trends Neurosci 1999; 22: 555-61.

17 Millar NS. Assembly and subunit diversity of nicotinic acetylcholine receptors. Biochem Soc Trans 2003; 31: 869-74.

18 Dani JA, Bertrand D. Nicotinic acetylcholine receptors and nicotinic cholinergic mechanisms of the central nervous system. Annu Rev Pharmacol Toxicol 2007; 47: 699-729.

19 Hogg RC, Raggenbass M, Bertrand D. Nicotinic acetylcholine receptors: from structure to brain function. Rev Physiol Biochem Pharmacol 2003; 147: 1-46.

20 Mazzaferro S, Gasparri F, New K, Alcaino C, Faundez M, Iturriaga Vasquez $\mathrm{P}$, et al. Non-equivalent ligand selectivity of agonist sites in (alpha4beta2)2alpha4 nicotinic acetylcholine receptors: a key determinant of agonist efficacy. J Biol Chem 2014; 289: 21795-806.

21 Grutter T, de Carvalho LP, Dufresne V, Taly A, Changeux JP. Identification of two critical residues within the Cys-loop sequence that determine fast-gating kinetics in a pentameric ligand-gated ion channel. J Mol Neurosci 2006; 30: 63-4.

22 Chatterjee S, Santos N, Holgate J, Haass-Koffler CL, Hopf FW, Kharazia $\mathrm{V}$, et al. The alpha5 subunit regulates the expression and function of alpha $4 *$-containing neuronal nicotinic acetylcholine receptors in the ventral-tegmental area. PLoS One 2013; 8: e68300.

23 Colombo SF, Mazzo F, Pistillo F, Gotti C. Biogenesis, trafficking and up-regulation of nicotinic ACh receptors. Biochem Pharmacol 2013; 86: 1063-73.

24 Palma E, Bertrand S, Binzoni T, Bertrand D. Neuronal nicotinic alpha7 receptor expressed in Xenopus oocytes presents five putative binding sites for methyllycaconitine. J Physiol 1996; 491 (Pt 1): 151-61.

25 Niesler B, Kapeller J, Hammer C, Rappold G. Serotonin type 3 receptor genes: HTR3A, B, C, D, E. Pharmacogenomics 2008; 9: 501-4.

26 Gotti C, Clementi F, Fornari A, Gaimarri A, Guiducci S, Manfredi I, et al. Structural and functional diversity of native brain neuronal nicotinic receptors. Biochem Pharmacol 2009; 78: 703-11.

27 Lochner M, Lummis SC. Agonists and antagonists bind to an A-A interface in the heteromeric 5- $\mathrm{HT}_{3 A B}$ receptor. Biophys J 2010; 98: 1494-502.

28 Perry E, Walker M, Grace J, Perry R. Acetylcholine in mind: a neurotransmitter correlate of consciousness? Trends Neurosci 1999; 22: 273-80.

29 Picciotto MR, Higley MJ, Mineur YS. Acetylcholine as a neuromodulator: cholinergic signaling shapes nervous system function and behavior. Neuron 2012; 76: 116-29.

30 Marks MJ. Genetic matters: thirty years of progress using mouse models in nicotinic research. Biochem Pharmacol 2013; 86: 110513.

31 Wu M, Robinson JE, Joiner WJ. SLEEPLESS is a bifunctional regulator of excitability and cholinergic synaptic transmission. Curr Biol 2014; 24: 621-9.

32 Yohn NL, Turner JR, Blendy JA. Activation of alpha4beta2*/alpha6beta2* nicotinic receptors alleviates anxiety during nicotine withdrawal without upregulating nicotinic receptors. J Pharmacol Exp Ther 2014; 
276-81.

349: 348-54.

33 Scerri C, Stewart CA, Balfour DJ, Breen KC. Nicotine modifies in vivo and in vitro rat hippocampal amyloid precursor protein processing in young but not old rats. Neurosci Lett 2012; 514: 22-6.

34 Ronde $\mathrm{P}$, Nichols RA. High calcium permeability of serotonin $5-\mathrm{HT}_{3}$ receptors on presynaptic nerve terminals from rat striatum. J Neurochem 1998; 70: 1094-103.

35 Funahashi M, Mitoh Y, Matsuo R. Activation of presynaptic $5-\mathrm{HT}_{3}$ receptors facilitates glutamatergic synaptic inputs to area postrema neurons in rat brain slices. Methods Find Exp Clin Pharmacol 2004; 26: 615-22.

36 Greenshaw AJ, Silverstone PH. The non-antiemetic uses of serotonin $5-\mathrm{HT}_{3}$ receptor antagonists. Clinical pharmacology and therapeutic applications. Drugs 1997; 53: 20-39.

37 Faerber L, Drechsler S, Ladenburger S, Gschaidmeier H, Fischer $W$. The neuronal $5-\mathrm{HT}_{3}$ receptor network after 20 years of research-evolving concepts in management of pain and inflammation. Eur $J$ Pharmacol 2007; 560: 1-8.

38 Thompson AJ, Lummis SCR. The $5-\mathrm{HT}_{3}$ receptor as a therapeutic target. Expert Opin Ther Targets 2007; 11: 527-40.

39 Walstab J, Rappold G, Niesler B. 5- $\mathrm{HT}_{3}$ receptors: role in disease and target of drugs. Pharmacol Ther 2010; 128: 146-69.

40 Kato S. Role of serotonin $5-\mathrm{HT}_{3}$ receptors in intestinal inflammation. Biol Pharm Bull 2013; 36: 1406-9.

41 Oda A, Tanaka H. Activities of nicotinic acetylcholine receptors modulate neurotransmission and synaptic architecture. Neural Regen Res 2014; 9: 2128-31.

42 Changeux JP. Nicotine addiction and nicotinic receptors: lessons from genetically modified mice. Nat Rev Neurosci 2010; 11: 389-401.

43 Ballesteros-Yanez I, Benavides-Piccione R, Bourgeois JP, Changeux JP, DeFelipe J. Alterations of cortical pyramidal neurons in mice lacking high-affinity nicotinic receptors. Proc Natl Acad Sci U S A 2010; 107: 11567-72.

44 Changeux JP, Taly A. Nicotinic receptors, allosteric proteins and medicine. Trends Mol Med 2008; 14: 93-102.

45 Taly A, Corringer PJ, Guedin D, Lestage P, Changeux JP. Nicotinic receptors: allosteric transitions and therapeutic targets in the nervous system. Nat Rev Drug Discov 2009; 8: 733-50.

46 Unwin N. Refined structure of the nicotinic acetylcholine receptor at 4A resolution. J Mol Biol 2005; 346: 967-89.

47 Brejc K, van Dijk WJ, Klaassen RV, Schuurmans M, van Der Oost J, Smit $A B$, et al. Crystal structure of an ACh-binding protein reveals the ligand-binding domain of nicotinic receptors. Nature 2001; 411: 269-76.

48 Kesters D, Thompson AJ, Brams M, van Elk R, Spurny R, Geitmann M, et al. Structural basis of ligand recognition in $5-\mathrm{HT}_{3}$ receptors. EMBO Rep 2013; 14: 49-56.

49 Price KL, Lillestol RK, Ulens C, Lummis SC. Varenicline interactions at the 5-HT receptor ligand binding site are revealed by 5-HTBP. ACS Chem Neurosci 2015; 6: 1151-7.

50 Hilf RJ, Dutzler R. X-ray structure of a prokaryotic pentameric ligandgated ion channel. Nature 2008; 452: 375-9.

51 Hilf RJ, Dutzler R. Structure of a potentially open state of a protonactivated pentameric ligand-gated ion channel. Nature 2009; 457: 115-8.

52 Hibbs RE, Gouaux E. Principles of activation and permeation in an anion-selective Cys-loop receptor. Nature 2011; 474: 54-60.

53 Miller PS, Aricescu AR. Crystal structure of a human $\mathrm{GABA}_{A}$ receptor. Nature 2014; 512: 270-5.

54 Hassaine G, Deluz C, Grasso L, Wyss R, Tol MB, Hovius R, et al. X-ray structure of the mouse serotonin $5-\mathrm{HT}_{3}$ receptor. Nature 2014; 512:
55 Palma E, Mileo AM, Eusebi F, Miledi R. Threonine-for-leucine mutation within domain M2 of the neuronal alpha(7) nicotinic receptor converts 5-hydroxytryptamine from antagonist to agonist. Proc Natl Acad Sci U S A 1996; 93: 11231-5.

56 Steward LJ, Boess FG, Steele JA, Liu D, Wong N, Martin IL. Importance of phenylalanine 107 in agonist recognition by the 5-hydroxytryptamine(3A) receptor. Mol Pharmacol 2000; 57: 124955.

57 Yakel JL. Gating of nicotinic ACh receptors: latest insights into ligand binding and function. J Physiol 2010; 588: 597-602.

58 Bisson WH, Westera G, Schubiger PA, Scapozza L. Homology modeling and dynamics of the extracellular domain of rat and human neuronal nicotinic acetylcholine receptor subtypes alpha4beta2 and alpha7. J Mol Model 2008; 14: 891-9.

59 Williams DK, Wang J, Papke RL. Positive allosteric modulators as an approach to nicotinic acetylcholine receptor-targeted therapeutics: advantages and limitations. Biochem Pharmacol 2011; 82: 915-30.

60 Young GT, Zwart R, Walker AS, Sher E, Millar NS. Potentiation of alpha7 nicotinic acetylcholine receptors via an allosteric transmembrane site. Proc Natl Acad Sci U S A 2008; 105: 14686-91.

61 Burgi JJ, Awale M, Boss SD, Schaer T, Marger F, Viveros-Paredes $\mathrm{JM}$, et al. Discovery of potent positive allosteric modulators of the alpha3beta2 nicotinic acetylcholine receptor by a chemical space walk in ChEMBL. ACS Chem Neurosci 2014; 5: 346-59.

62 Pandya AA, Yakel JL. Effects of neuronal nicotinic acetylcholine receptor allosteric modulators in animal behavior studies. Biochem Pharmacol 2013; 86: 1054-62.

63 Dey R, Chen L. In search of allosteric modulators of $\alpha 7-n A C h R$ by solvent density guided virtual screening. J Biomol Struct Dyn 2011; 28: 695-715.

64 Li SX, Huang S, Bren N, Noridomi K, Dellisanti CD, Sine SM, et al. Ligand-binding domain of an alpha7-nicotinic receptor chimera and its complex with agonist. Nat Neurosci 2011; 14: 1253-9.

65 Huang S, Li SX, Bren N, Cheng K, Gomoto R, Chen L, et al. Complex between alpha-bungarotoxin and an alpha7 nicotinic receptor ligandbinding domain chimaera. Biochem J 2013; 454: 303-10.

66 Wang C, Jiang Y, Ma JM, Wu HX, Wacker D, Katritch V, et al. Structural basis for molecular recognition at serotonin receptors. Science 2013; 340: 610-4.

67 Althoff T, Hibbs RE, Banerjee S, Gouaux E. X-ray structures of GluCl in apo states reveal a gating mechanism of Cys-loop receptors. Nature 2014; 512: 333-7.

68 Thompson AJ, Lummis SC. A single ring of charged amino acids at one end of the pore can control ion selectivity in the $5-\mathrm{HT}_{3}$ receptor. Br J Pharmacol 2003; 140: 359-65.

69 Corringer PJ, Bertrand S, Galzi JL, Devillers-Thiery A, Changeux JP, Bertrand D. Mutational analysis of the charge selectivity filter of the alpha7 nicotinic acetylcholine receptor. Neuron 1999; 22: 831-43.

70 Kelley SP, Dunlop JI, Kirkness EF, Lambert JJ, Peters JA. A cytoplasmic region determines single-channel conductance in $5-\mathrm{HT}_{3}$ receptors. Nature 2003; 424: 321-4.

71 Carland JE, Cooper MA, Livesey MR, Hales TG, Peters JA, Lambert JJ. Mutagenic analysis of the intracellular portals of the human $5-\mathrm{HT}_{3 \mathrm{~A}}$ receptor. J Biol Chem 2013; 288: 31592-601.

72 Rahman S. Nicotinic receptors as therapeutic targets for drug addictive disorders. CNS Neurol Disord Drug Targets 2013; 12: 63340.

73 Pollak KI, Oncken CA, Lipkus IM, Lyna P, Swamy GK, Pletsch PK, et al. Nicotine replacement and behavioral therapy for smoking cessation in pregnancy. Am J Prev Med 2007; 33: 297-305. 
74 Rollema H, Shrikhande A, Ward KM, Tingley FD 3rd, Coe JW, O'Neill $\mathrm{BT}$, et al. Pre-clinical properties of the alpha4beta2 nicotinic acetylcholine receptor partial agonists varenicline, cytisine and dianicline translate to clinical efficacy for nicotine dependence. $\mathrm{Br} J$ Pharmacol 2010; 160: 334-45.

75 Nides M, Glover ED, Reus VI, Christen AG, Make BJ, Billing CB Jr, et al. Varenicline versus bupropion SR or placebo for smoking cessation: a pooled analysis. Am J Health Behav 2008; 32: 664-75.

76 Papke RL, Dwoskin LP, Crooks PA. The pharmacological activity of nicotine and nornicotine on nAChRs subtypes: relevance to nicotine dependence and drug discovery. J Neurochem 2007; 101: 160-7.

77 Mineur YS, Einstein EB, Seymour PA, Coe JW, O'Neill B T, Rollema H, et al. alpha4beta2 nicotinic acetylcholine receptor partial agonists with low intrinsic efficacy have antidepressant-like properties. Behav Pharmacol 2011; 22: 291-9.

78 Bain EE, Apostol G, Sangal RB, Robieson WZ, McNeill DL, Abi-Saab WM, et al. A randomized pilot study of the efficacy and safety of ABT089, a novel alpha4beta2 neuronal nicotinic receptor agonist, in adults with attention-deficit/hyperactivity disorder. J Clin Psychiatry 2012; 73: 783-9.

79 Bain EE, Robieson W, Pritchett Y, Garimella T, Abi-Saab W, Apostol G, et al. A randomized, double-blind, placebo-controlled phase 2 study of alpha4beta2 agonist ABT-894 in adults with ADHD. Neuropsychopharmacology 2013; 38: 405-13.

80 Rao TS, Adams PB, Correa LD, Santori EM, Sacaan Al, Reid RT, et al. Pharmacological characterization of (S)-(2)-5-ethynyl-3-(1-methyl2-pyrrolidinyl)pyridine $\mathrm{HCl}$ (SIB-1508Y, Altinicline), a novel nicotinic acetylcholine receptor agonist. Brain Res 2008; 1234: 16-24.

81 Toyohara J, Hashimoto K. alpha7 Nicotinic receptor agonists: Potential therapeutic drugs for treatment of cognitive impairments in schizophrenia and Alzheimer's disease. Open Med Chem J 2010; 4: 37-56.

82 Hirata T, Keto Y, Funatsu T, Akuzawa S, Sasamata M. Evaluation of the pharmacological profile of ramosetron, a novel therapeutic agent for irritable bowel syndrome. J Pharmacol Sci 2007; 104: 263-73.

83 Hope AG, Peters JA, Brown AM, Lambert JJ, Blackburn TP. Characterization of a human 5-hydroxytryptamine3 receptor type A (h5-HT3R-AS) subunit stably expressed in HEK293 cells. Br J Pharmacol 1996; 118: 1237-45.

84 Lankiewicz S, Lobitz N, Wetzel CH, Rupprecht R, Gisselmann G, Hatt $\mathrm{H}$. Molecular cloning, functional expression, and pharmacological characterization of 5-hydroxytryptamine 3 receptor cDNA and its splice variants from guinea pig. Mol Pharmacol 1998; 53: 202-12.

85 Brady CA, Stanford IM, Ali I, Lin L, Williams JM, Dubin AE, et al. Pharmacological comparison of human homomeric $5-\mathrm{HT}_{3 \mathrm{~A}}$ receptors versus heteromeric $5-\mathrm{HT}_{3 \mathrm{~A} / 3 \mathrm{~B}}$ receptors. Neuropharmacology 2001; 41: 282-4.

86 Mehta M, Adem A, Kahlon MS, Sabbagh MN. The nicotinic acetylcholine receptor: smoking and Alzheimer's disease revisited. Front Biosci (Elite Ed) 2012; 4: 169-80.

87 Wu ZS, Cui ZC, Cheng H, Fan C, Melcher K, Jiang Y, et al. High yield and efficient expression and purification of the human $5-\mathrm{HT}_{3 \mathrm{~A}}$ receptor. Acta Pharmacol Sin 2015; 36: 1013-23.

88 Cheng H, Fan C, Zhang SW, Wu ZS, Cui ZC, Melcher K, et al. Crystallization scale purification of alpha7 nicotinic acetylcholine receptor from mammalian cells using a BacMam expression system. Acta Pharmacol Sin 2015; 36: 1024-32.

This work is licensed under the Creative Commons Attribution-NonCommercial-No Derivative Works 3.0 Unported License. To view a copy of this license, visit http://creativecommons.org/licenses/ by-nc-nd/3.0/ 